\title{
Performance Appraisal Standardization Of Educational Manpower And Education Management
}

\author{
Pujiarti 1) \\ pujiarti.pujiarti@ubd.ac.id \\ Rinintha Parameswari 2) \\ rinintha.parameswari@ubd.ac.id \\ Suhendar Janamarta ${ }^{3}$ \\ suhendar.janamarta@ubd.ac.id
}

1) 2) 3) Buddhi Dharma University Tangerang, Banten, Indonesia.

\begin{abstract}
Performance appraisal is a planned process and must be carried out periodically to measure the success of the education and learning process. The author limits the discussion in this article to the aspects that must be assessed for educators and education personnel. The current problems are the absence of segregation of the assessed aspects, there are not any standardized of scoring system, and determination of benchmarks used in the assessment. The results of the performance assessment lie with the appraiser who assesses the teaching staff and education staff objectively and not subjectively based on the aspects that must be assessed. The success of the education and teaching process lies in the contribution of the teaching and education personnel performance according to predetermined standards.
\end{abstract}

Keywords : Standardization, Performance Appraisal, Educators, Education Personnel 


\section{Preliminary}

Human resources are the most important resources, in addition to other resources owned by the organization. Existing human resources must be required to contribute in realizing the goals the organization wants to achieve. To be able to achieve these goals, many factors influence including internal organizational factors such as organizational commitment and performance appraisal systems as indicators of compensation. These two components have a role in determining the performance produced by employees. A higher performance implies an increase in efficiency, effectiveness, or a higher quality of completing a series of tasks assigned to an employee in an organization.

In general, performance is the achievement of results for the implementation of certain tasks (Simanjuntak, 2011). The level of commitment, both organizational commitment to employees, as well as between employees and the organization is needed, because through these commitments a professional working climate will be created and result in increased performance. In addition, employees work wholeheartedly and feel that these employees are an important part of an organization. An objective and fair performance appraisal system, especially in relation to employee performance, should be owned by the organization.

With a standardized appraisal system, an employee will produce an increase in performance which is expected to achieve organizational goals. The performance appraisal system also provides a tangible measure of individual value to the organization. In other words, managing employees as human resources in relation to producing positive performance for the organization is important to pay attention to and be managed. The organization is expected to be able to manage employees as a resource that produces output in the form of optimal performance.

Employees as human resources owned by the organization have internal and external drives in relation to the work that is realized. Internal employee encouragement is a drive that comes from within the employee, such as: commitment and loyalty. Meanwhile, external drives are stimulated directly by the organization, such as the standardization of the performance appraisal system as the basis for making compensation schemes.

Performance appraisal is a method of evaluating and rewarding employee performance. Performance appraisal focuses on appraisal as a process of measuring the extent to which an employee or group of employees can benefit the organization to achieve the goals set. Individual performance can be improved if there is an appropriate between work and ability. Individual performance is influenced by job satisfaction. Job satisfaction is an individual's feelings about his job. This feeling is in the form of an assessment of how far the overall job is able to satisfy their needs. In this case an evaluation is needed, which is then known as a performance appraisal.

\section{Identification of Problems}

Based on the background above, several problems that are still faced by organizations, especially in the field of education in relation to standardization of performance appraisal, are as follows:

1. There is not separation of the aspects assessed between teaching staff and educational staff. 
2. The assessment system for teaching staff and education staff has not been standardized.

3. There is not determination of benchmarks used in the assessment, both for teaching staff and education personnel.

\section{Theoretical Basis}

\section{Definition of Standardization :}

Standardization is simultaneously effort to form standards. Standard is a rule, usually used for guidance but can also be mandatory (minimalize in practical), specifying and using an object or characteristics of a process and / or characteristics of a method.

2. Definition of Performance Appraisal :

According to Pathania in his book Effectiveness of Performance Appraisal System of Insurance Sector (2011) state that: "Performance Appraisal as a tool used to measure the standards set by Human Resource Management".

\section{Definition of Educators :}

Educators are professionals in charge of planning and implementing the learning process, assessing learning outcomes, conducting guidance and training, and conducting research and community service, especially for educators in tertiary institutions (Law Number 20 of 2003 Article 39 (2)).

4. Definition of Educational Personnel :

Education personnel are members of society who are devoted and appointed to support the implementation of education (Law Number 20 Year 2003 Article 1 (Chapter 1 General Provisions)).

\section{Research Methods}

The notion of research methods is a scientific step to obtain data with specific purposes and uses (Sugiyono, 2011). This study uses qualitative research methods, namely research used to investigate, discover, describe, and explain the quality or features of social influences that cannot be explained, measured or described through a quantitative approach (Saryono, 2010).

\section{Results and Discussion}

1. Performance Appraisal Components for Educators, covering aspects :
a. Academic qualifications.
b. Education and training.
c. Teaching experience.
d. Planning and implementation of learning.
e. Assessment from superiors and supervisors.
f. Academic achievement.
g. Professional development work.
h. Participation in scientific forums.
i. Organizational experience in educational and social fields.
j. The awards that is relevant to the field of education. 


\begin{tabular}{|c|c|c|}
\hline Variable & Sub Variable & Indicator \\
\hline \multirow{10}{*}{ Competence } & $\begin{array}{l}\text { Academic } \\
\text { Qualifications }\end{array}$ & $\begin{array}{l}\text { Have the minimum level of education } \\
\text { that an educator must have master } \\
\text { degree. }\end{array}$ \\
\hline & $\begin{array}{l}\text { Education and } \\
\text { Training }\end{array}$ & $\begin{array}{l}\text { A systematic process to improve and } \\
\text { develop oneself in learning knowledge, } \\
\text { skills, and abilities to achieve personal } \\
\text { and organizational goals. }\end{array}$ \\
\hline & $\begin{array}{l}\text { Learning } \\
\text { Experience }\end{array}$ & $\begin{array}{l}\text { Ability that must be possessed by an } \\
\text { educator, namely being able to } \\
\text { accommodate any changes in technology } \\
\text { and the behavior of their students. }\end{array}$ \\
\hline & $\begin{array}{l}\text { Planning and } \\
\text { Implementation } \\
\text { of Learning }\end{array}$ & $\begin{array}{l}\text { The procedure and organization of } \\
\text { learning to achieve a basic competency } \\
\text { set out in content standards and } \\
\text { described in the syllabus. }\end{array}$ \\
\hline & $\begin{array}{l}\text { Assessment } \\
\text { from Superior } \\
\text { and } \\
\text { Supervisors }\end{array}$ & $\begin{array}{l}\text { Assessment of academic achievement } \\
\text { achieved by an educator in the } \\
\text { development of his profession, for } \\
\text { example, lecturer certification. }\end{array}$ \\
\hline & $\begin{array}{l}\text { Academic a } \\
\text { Achievement }\end{array}$ & $\begin{array}{l}\text { The success of an educator in developing } \\
\text { their scientific field. }\end{array}$ \\
\hline & $\begin{array}{l}\text { Professional } \\
\text { Development } \\
\text { Work }\end{array}$ & $\begin{array}{l}\text { An opus that shows an effort to develop } \\
\text { a scientific profession from an educator, } \\
\text { such as obtaining a scientific certificate } \\
\text { CMA (Certified Management Accounting), } \\
\text { CDM (Certified Digital Marketing). }\end{array}$ \\
\hline & $\begin{array}{l}\text { Participation in } \\
\text { Scientific } \\
\text { Forums }\end{array}$ & $\begin{array}{l}\text { The participation of an educator in } \\
\text { various activities such as seminars } \\
\text { (national or international scale), as a } \\
\text { participant speaker. }\end{array}$ \\
\hline & $\begin{array}{l}\text { Organizational } \\
\text { Experience in } \\
\text { the Educational } \\
\text { and Social } \\
\text { Sector }\end{array}$ & $\begin{array}{l}\text { It is a reflection of the maturity of an } \\
\text { educator in self-development in an } \\
\text { organization, engaged in education and } \\
\text { other fields, such as occupying structural } \\
\text { positions. }\end{array}$ \\
\hline & $\begin{array}{l}\text { Appreciation } \\
\text { that is Relevant } \\
\text { to the Field of } \\
\text { Education }\end{array}$ & $\begin{array}{l}\text { The readiness of an educator to take part } \\
\text { in various certification programs as a } \\
\text { form of appreciation for their } \\
\text { performance. }\end{array}$ \\
\hline
\end{tabular}

2. Performance Appraisal Components for Educational Personnel, including aspects :

a. Technical : initiative, innovation, communication, adaptability, motivation, cooperation, and independence.

b. Manajerial : leadership, problem solving, and decision making. 
c. Behavior : discipline, commitment, appearance, ethics and courtesy, honesty, and loyalty.

\begin{tabular}{|c|c|c|}
\hline Variable & Sub Variable & Indicator \\
\hline \multirow{7}{*}{ Technical } & Initiative & $\begin{array}{l}\text { Able to think and act quickly and } \\
\text { precisely to achieve goals. }\end{array}$ \\
\hline & \multirow[t]{2}{*}{ Innovation } & $\begin{array}{l}\text { Have new ideas for solving problems or } \\
\text { tasks. }\end{array}$ \\
\hline & & Doing work effectively and efficiently. \\
\hline & \multirow[t]{3}{*}{ Communication } & $\begin{array}{l}\text { Able to convey ideas or arguments } \\
\text { clearly to others. }\end{array}$ \\
\hline & & Excellent in Public Speaking. \\
\hline & & $\begin{array}{l}\text { Able to provide direction or explanation } \\
\text { to subordinates or colleagues. }\end{array}$ \\
\hline & Adaptability & $\begin{array}{l}\text { Able to hold and use information } \\
\text { technology well. }\end{array}$ \\
\hline \multirow{5}{*}{ Technical } & Motivation & $\begin{array}{l}\text { Show a willingness to work } \\
\text { wholeheartedly. }\end{array}$ \\
\hline & \multirow[t]{2}{*}{ Cooperation } & $\begin{array}{l}\text { Can build relationships, horizontally } \\
\text { and vertically up and down or } \\
\text { interacting or collaborating with other } \\
\text { people. }\end{array}$ \\
\hline & & $\begin{array}{l}\text { Make a positive and productive } \\
\text { contribution in every job. }\end{array}$ \\
\hline & \multirow[t]{2}{*}{ Independence } & $\begin{array}{l}\text { Can carry out duties and job } \\
\text { responsibilities } \\
\text { supervision from superiors. }\end{array}$ \\
\hline & & $\begin{array}{l}\text { Able to solve problems and make } \\
\text { decisions quickly and precisely } \\
\text { according to their authority. }\end{array}$ \\
\hline \multirow{7}{*}{ Managerial } & \multirow[t]{4}{*}{ Leadership } & $\begin{array}{l}\text { Have a vision and can set goals for the } \\
\text { work unit. }\end{array}$ \\
\hline & & $\begin{array}{l}\text { Able to lead, influence, motivate, and } \\
\text { provide direction to subordinates or } \\
\text { colleagues properly. }\end{array}$ \\
\hline & & Able to empower subordinates. \\
\hline & & $\begin{array}{l}\text { Upholding the integrity (honesty and } \\
\text { adherence to regulations) and credibility } \\
\text { of the institution. }\end{array}$ \\
\hline & \multirow[t]{2}{*}{$\begin{array}{l}\text { Problem } \\
\text { Solving }\end{array}$} & $\begin{array}{l}\text { Able to identify problems and determine } \\
\text { solutions. }\end{array}$ \\
\hline & & $\begin{array}{l}\text { Able to provide alternative solutions to } \\
\text { superiors for several problems. }\end{array}$ \\
\hline & $\begin{array}{l}\text { Decision } \\
\text { Making }\end{array}$ & $\begin{array}{l}\text { Able to choose the most appropriate } \\
\text { solution to solve the problem. }\end{array}$ \\
\hline
\end{tabular}




\begin{tabular}{|c|c|c|}
\hline & & Brave to take risks for decisions made. \\
\hline Variable & Sub Variable & Indicator \\
\hline \multirow{4}{*}{ Behavior } & \multirow[t]{2}{*}{ Discipline } & $\begin{array}{l}\text { Low frequency of truancy or permits } \\
\text { during working hours. }\end{array}$ \\
\hline & & $\begin{array}{l}\text { Ability to manage working time } \\
\text { effectively and efficiently. }\end{array}$ \\
\hline & Commitment & $\begin{array}{l}\text { Highly committed to institutional } \\
\text { development, organization and self- } \\
\text { development. }\end{array}$ \\
\hline & Appearance & $\begin{array}{l}\text { Physical appearance that is always neat } \\
\text { and according to the rules. }\end{array}$ \\
\hline \multirow{7}{*}{ Behavior } & \multirow{2}{*}{$\begin{array}{l}\text { Ethics and } \\
\text { Courtesy }\end{array}$} & $\begin{array}{l}\text { Polite in interacting and communicating } \\
\text { with fellow colleagues. }\end{array}$ \\
\hline & & $\begin{array}{l}\text { Have good manners, both in } \\
\text { communication and work. }\end{array}$ \\
\hline & \multirow[t]{2}{*}{ Honesty } & Speak and behave simply. \\
\hline & & Consistent between speech and action. \\
\hline & \multirow[t]{3}{*}{ Loyalty } & $\begin{array}{l}\text { Carry out orders from superiors with all } \\
\text { efforts. }\end{array}$ \\
\hline & & $\begin{array}{l}\text { Do not argue with, refuse, or disobey } \\
\text { orders from superiors. }\end{array}$ \\
\hline & & $\begin{array}{l}\text { Proud and responsible for their duties } \\
\text { and work. }\end{array}$ \\
\hline
\end{tabular}

\section{Performance Appraisal System for Educators}

The teaching staff performance appraisal system can use several methods, including :

a. Rating Scale Method :

$\begin{array}{rll}\text { Example }: 90-100 & =\text { Very Good } & =A \\ 80-89 & =\text { Good } & =\mathrm{B} \\ 70-79 & =\text { Good Enough } & =\mathrm{C} \\ 60-69 & =\text { Deficient } & =\mathrm{D} \\ 0-59 & =\text { Very Deficient } & =\mathrm{E}\end{array}$

b. Check List Method :

Using filling forms regarding the factors that are assessed by paying attention to the aspects of task / job completion (in column form). The forms below can be used to complement the aspects assessed using the rating scale method.

1. Explain the positive things that person has done during this assessment period!

2. Describe things that need to be improved or developed for the person concerned!

3. Explain the development plan or performance improvement for the career path concerned (short term, medium term, and long term)! 


\section{Performance Appraisal System for Education Personnel}

The educational staff performance appraisal system can use several methods, including :

a. Rating Scale Method :

$$
\begin{aligned}
& \text { Example : } 90-100=\text { Very Good }=\mathrm{A} \\
& 80-89=\text { Good }=\mathrm{B} \\
& 70-79=\text { Good Enough } \quad=\mathrm{C} \\
& 60-69=\text { Deficient }=\mathrm{D} \\
& 0-59=\text { Very Deficient }=\mathrm{E}
\end{aligned}
$$

\section{b. Check List Method :}

Using filling forms regarding the factors that are assessed by paying attention to the aspects of task / job completion (in column form). The forms below can be used to complement the aspects assessed using the rating scale method.

1. Explain the positive things that person has done during this assessment period!

2. Describe things that still need to be improved or developed for the person concerned!

3. Explain the development plan or performance improvement for the career path concerned (short term, medium term, and long term)!

\section{Benchmark Performance Assessment for Educators}

The benchmarks of the teaching staff's performance are the success/ achievement of the main task of the Tridharma of Higher Education, and fulfilling the BKD (Lecturer Workload).

Example :

An Educator can fulfill his main task (Tridharma = Teaching, Research, and Community Service but does not reach his BKD

(Lecturer Workload $=12$ credits $\longrightarrow \quad$ Teaching 9 credits, Research and Community Service 3 credits).

The assessment as follows :

a. Fulfill the main task and BKD.

b. Fulfill the main task and BKD 75\%.

c. Fulfill the main task and BKD less than $75 \%$.

\section{Benchmarks of Performance Appraisal for Education Personnel}

The benchmark for the performance of education personnel is their productivity in achieving organizational goals, in line with the vision and mission of the college concerned. 
Bibliography

Afifuddin. Dasar-dasar Manajemen. Bandung: Alfabeta. 2014.

Dessler, G. Manajemen Sumber Daya Manusia (10 ed.). Jakarta: PT. Indeks. 2010.

Keistiawan, Muhammad, dkk. Manajemen Pendidikan. Yogyakarta: CV. Budi Utama. 2017.

Lembar Faktor Penilaian Kinerja Karyawan (PK2) Struktural, Universitas Katolik Indonesia Atma Jaya.

Lembar Faktor Penilaian Kinerja Karyawan (PK2) Kependidikan, Universitas Katolik Indonesia Atma Jaya.

Mangkunegara, A. P. Evaluasi Kinerja Sumber Daya Manusia. Jakarta: Refika Aditama. 2006.

Mathis, R. dan Jackson, J. Manajemen Sumber Daya Manusia. Jakarta: Salemba Empat. 2006.

Noor, Juliansyah. Penelitian Ilmu Manajemen (Tinjauan Filosofi dan Praktis). Jakarta: Kencana Prenada Media Group. 2013.

Panggabean, Mutiara S. Manajemen Sumber Daya Manusia. Edisi Kedua. Bogor: Ghalia Indonesia. 2002.

Pathania, D. K., Nag, A. K., dan Pathak, A. D. Effectiveness of Performance Appraisal System of Insurance Sector - A Study of Himachal Pradesh. Gurukul Business Review (GBR), 19-23. 2011.

Permendiknas Nomor 18 Tahun 2007.

Saryono. Metodologi Penelitian Kualitatif dan Kuantitatif. Jakarta: Graha Ilmu. 2010.

Simanjuntak, Payaman J. Manajemen dan Evaluasi Kinerja, Jakarta: FEUI. 2011.

Sugiyono. Metode Penelitian Kuantitatif, Kualitatif, dan R \& D. Jakarta: Alfabeta. 2011.

Sukarna. Dasar-dasar Manajemen. Bandung: CV. Mandar Maju. 2011.

Undang-undang Republik Indonesia Nomor 20 Tahun 2003 tentang Sistem Pendidikan.

Umar, Husaini. Manajemen Teori, Praktik, dan Riset Pendidikan. Jakarta: PT. Bumi Aksara. 2016. 